latitudes greater than $60^{\circ} \mathrm{N}$. This escape was probably associated with subsidence of stratospheric air, according to Brewer and Dobson, and suggests a virtual disappearance of the troposphere at these latitudes.

Most of the polar debris appeared in the troposphere during the first six months of 1959. A small residue from the polar injection may have lodged above the lower stratosphere. This residue would have been brought down, together with older debris, during subsequent winter subsidences, and appeared as a well-mixed fraction of the fission product concentrations measured during 1960 and 1961 .

The proportion of polar debris in the lower stratosphere above the United Kingdom in 1959 was lower than in the troposphere. This effect may be restricted in extent and have no great significance in a global model.
${ }^{1}$ Cunninghame, J. G., J. Inorg. Nucl. Chem., 5, 1 (1957).

${ }^{2}$ Ford, G. P., and Gilmore, J. S., Los Alamos Report LA-1997, Office of Technical Service, Washington, D.C. (1956).

${ }^{8}$ Lockhart, L. B. Baus, R. A., Patterson, R. L., and Saunders, A. W., J. Geophys, Res., 65 (6), 1711 (1960).

‘ Lockhart, K. B., Patterson, R. L., Saunders, A. W., and Black, R. W., J. Geophys. Res., 65 (12), 3987 (1960).

s Crooks, R. N., Osmond, R. G., Fisher, E. M. R., Owers, M. J., and Evett, T. W., Atomic Energy Research Eistablishment, Harwell, $A E R E R-3349$ (1960)

- Crooks, R. N.. et al., Atomic Energy Research Establishment, Harwell, $A \ddot{E} R E R-3766$ (to be published).

'Stewart, N. G., Crooks, R. N., and Fisher, E. M. R., Atomic Energy Research Establishment, Harwell, $A E R E$. MP. R., Atomic Ener

- Peirson, D. H., Crooks, R. N., and Fisher, E. M. R., A tomic Energy Research Establishment, Harwell, $A E R E R-3358$ (1960).

- Stewart, N. G., Osmond, R. G. D., Crooks, R. N., and Fisher, E. M. R. A tomic Energy Research Establishment, Harwell, $A E R E$ E $P$ \} R2354 (1958).

${ }^{10}$ Brewer, A. W., Quart. J. Roy. Met. Soc., 75, 351 (1949).

${ }^{11}$ Goldsmith, P., and Brown, F., Nature, 191, 1033 (1961).

${ }^{2}$ Martell, E. A., Science, 129, 1197 (1958).

${ }^{33}$ Parker, R. P., and Crookall, J. O., Nature, 190, 574 (1961).

\title{
ELECTRICAL POWER DEVELOPMENT
}

T

HE annual meeting in June of the British Electrical Power Convention was held, as has been customary in recent years, at Eastbourne, under the presidency of Sir John Pickles, chairman of the South of Scotland Electricity Board. In his presidential address he gave emphasis to the theme of the Convention-" "Electricity in the Prosperity and Welfare of the Nation". The address was in the form of a review and prospect of the electricity supply industry in Britain from A.D. 1880 to 2000.

Sir John considered that there would be a doubling of consumption in the ten years to 1970 and that this rate of increase would be maintained, with a further doubling by 1980 , or 1985 at the latest. This implies an increase in the country's installed generating plant capacity, at present $32,000 \mathrm{MW}$., up to 100,000 MW., the greater part of this probably being nuclear. There would probably be 1000-MW. single generating sets, and their operation, together with that of their boilers, would be controlled by computers. In transmission a 750-kV. system seems not unlikely. Sir John concluded by referring to the possibilities of direct conversion of heat to electricity without the intervention of a steam cycle, attention being focused on thermionic, thermo-electric and magnetohydrodynamic generation. The latter, comprising direct generation by the passage of hot gas through a magnetic field, is the most promising. Nuclear fission may well prove highly suitable as a heat source.

The second speaker, Sir Christopher Hinton, chairman of the Central Electricity Generating Board, described the British electricity distribution system from the inception of the $132-\mathrm{kV}$. grid, which was intended for the transfer of energy between the large self-contained areas under conditions of difficulty or emergency. Much expert opinion at that time held that it would be impossible to interconnect the complete system without leading, under conditions of rapidly changing demand, to major power flows which could not safely be handled. Notwithstanding this, the London control engineers interconnected all the separate areas by means of the grid "to see what would happen". The interconnected system - the largest in the world controlled from one centre-has worked ever since. Various extensions and reinforcing interconnexions have been added, giving additional security and flexibility.
Work carried out at the formation of the British Electricity Authority and the area boards under the Electricity Act of 1947 showed a sound case for siting new generating plant near coalfields. This implied the provision of a higher voltage transmission system superimposed on the existing grid. A transmission voltage of $275 \mathrm{kV}$. was selected, this being the next higher International Electrotechnical Commission standard. It was considered that this voltage is not so high as to lead to possible insulation difficulties in the atmosphere of Great Britain. Tower clearances, however, allow for up-rating in the future to 380 $\mathrm{kV}$.- the next higher level-when insulation problems have been solved. So the $275-\mathrm{kV}$. super grid system in Britain was formed, developing mainly into ring mains of double-circuit lines connecting large-capacity generating stations and substations with transformation, usually to $132 \mathrm{kV}$. Transmission is by no means the junior partner of generation: it is perhaps dominant, for without the present highly developed transmission system-planned with foresight and wisdom by the old Central Electricity Board and those associated with it-the modern 2000-MW. generating station would be impracticable.

Sir Christopher Hinton reported that the maximum demand on the system so far was $24,449 \mathrm{MW}$., on December 13, 1960, and he suggested that this might be trebled in fifteen to twenty years time. The heaviest concentration of power stations would be in the central coalfields, with others in North Wales, the Severn Estuary, the Bristol Channel, the central south coast, the Thames Estuary, south-east Kent and the East Anglian coasts. He showed a map giving the distribution of power expected in the mid1970 's, when the maximum demand is likely to be $70,000 \mathrm{MW}$. and the projected $400 \mathrm{kV}$. supergrid fully operative. Nuclear generation should by then account for 30 per cent of the total consumption, indigenous fuel and oil consumption being roughly doubled. The movement of coal long distances by rail should virtually have ceased by this time, and sea-borne supplies reduced to roughly half their present value. As the load grows beyond 70,000 MW. in the years after 1975 , it is possible that a $700-\mathrm{kV}$. 'large mesh' network will be superimposed on the $400 / 132-\mathrm{kV}$. system. 


\section{№. 4802 November 11, $1961 \quad$ N A T U R E}

Sir Christopher continued by explaining the many factors not susceptible of control by the area boards which make accurate forecasting of future needs very difficult. He referred to shifts of population, town planning legislation and Government decisions on residential and industrial development. Forecasting is simple on a national scale and difficult on a local scalo.

About 40 per cent of the area of England and Wales is subject to restriction of some sort or other on the ground of amenity; but opposition to the construction of transmission lines and equipment is sometimes just as severe in industrial towns. Yet a transmission system of the present type is vital to British industry and essential if the very large stations (small in number and of high efficiency) are to be built. Although the public would not tolerate the ever-increasing extension of the network to a stage rightly described as a 'wirescape', underground cables for all additions to the network are out of the question on ground of cost. (A figure of about $£ 100$ million a year would be involved, representing $6 d$. on the standard rate of income tax, or 20 per cent on the bulk tariff.) The solution, perhaps a compromise, is to place underground the lower-cost distribution systems and leave tho very high-voltage transmission system in the form of lines on towers. The latter must be accepted as canals, railways and motorways are, but the design of the structures must be the most graceful that can be dovised and their routing must be most carefully planned. Sir William Holford set out in a paper to the Royal Society of Arts valuable rules relating to the siting of trans. mission lines. Switching stations, too, are now being most carefully considered. Sir Christopher Hinton concluded by emphasizing that the problem of visual amenity is one of the greatest facing the industry.

Mr. R. R. B. Brown, chairman of the Southern Electricity Board, presented a paper entitled "Some Aspects of Efficiency and Economy in Distribution". He reported that the national investment in distribution assets stands at more than $£ 1,000$ million, and additional expenditure at the rate of about $£ 100$ million annually is necessary to mont the expanding needs of the nation. Mr. Brown showed ways in which investment economies have been and will be achieved; and he dealt with tariff structures devised to encourage the full and efficient use of distribution systems. An interesting point made in connexion with standardization was that less than a hundred thousand consumers out of some 16 million now roceive direct current supplies; consumers served by non-standard alternating current systems number about $1,500,000$.

A paper by Dr. A. E. Grauer, chairman and president of the British Columbia Electric Co., Ltd., was on "The Electrical Power Industry in Canada". Canada, with a population of only 18 millions, is one of the world's largest producers (and consumers) of electric power. On a total output basis, she is behind the United States and the U.S.S.R., but on a par with the United Kingdom. Canada is second only to Norway on a per capita basis. Much of Canada's power is, of course, hydro-electric, and in Quebec power-rates are less than a third of the Canadian-American average. In Ontario and Manitoba they are about half the average in the United States. Canada's impressive power growth has been predominantly due to important power-consuming industries, smelting aluminium, refining copper, nickel and titanium and manufacturing inorganic chemicals. This growth has helped to open up new territory and expand Canada's world trade.

It is interesting that primary jurisdiction over natural resources, including water, was given to the Provincial Governments rather than to the Federal Government, and this, together with the huge areas of most of the provinces, has resulted in electrical utilities each essentially operating within one province. There are no electrical utilities which are national in scope.

Much of Canada's land mass (in aroa almost equal to China, which is itself second only to the U.S.S.R.) is virtually uninhabited, and population has tended to concentrate in a few areas strung mostly along the southern border and separated from each other by hundreds of miles. Almost a third of tho population lives in the southern tip of Ontario. Nearly ten million Canadians occupy an area less than that of the United Kingdom.

The manner in which the electric power industry is organized varies a great deal from one province to another. In some provinces there is practically no private ownership, in others practically no public ownership ; in others there is a mixture of both. The sizes of the utilities differ considerably, from Ontario Hydro, with a total capacity in excess of 6,000 MW. to quite small undertakings. Publicly owned utilities are usually run by a small commission reporting directly to the Cabinot. Investor-owned utilities operate under a Public Utilities Act adminis. tered by a Commission appointed by the Provincial Government. Fair rates are set by the Commission.

Canadians used, in $1959,4,300$ units of electrical enorgy per residential customer as compared with 3,700 units in the United States and about 2,000 units in the United Kingdom. One possible reason is that about 80 per cent of Canadians live in single or duplex dwellings. Also, the straight block-rate, with no demand charge, is almost universal, except for house heating. Off-peak tariffs are not used in Canada : industry works mainly on a three-shift system. It is interesting that Dr. Grauer's Company estimates each customer's bill for a ten-month period, sonds him a bill each month for a tenth of this amount, and then balances the books by a payment of the difference oither way at the end of the period.

Regarding rate of growth of electrical consumption, a relatively low figure might be expected from an already high consumption. Estimates point to an average figure of more than 6 per cont per annum and require the construction of more than 50,000 MW. of new capacity by 1980 . It is expected that most of the money to finance this will continue to be raised in Canada. This does not necessarily apply to the Peace River (British Columbia) and Hamilton Falls (Labrador) developments. It would appear that here are opportunities for British investment in Canada.

Canada's commercial water-power potential is considered by Dr. Grauer to be 70,000-80,000 MW. : the present installed turbine capacity is about $20,000 \mathrm{MW}$. The largest undeveloped hydro resources arc in Quebec and British Columbia, with Newfoundland and Manitoba following. Canada and the United States have, of course, signed a treaty respecting the Columbia River and construction is expected to start in 1962, with output of electrical energy by 1966.

Dr. Grauer made some interesting remarks concerning the development of thermal generation. The latter is necessary in some main industrial 
centres because of the existing full development of nearby water resources and because of the increasing costs of more remote hydro development. Steamelectric generation near the load centres is tending to cost less, improvements in design offsetting inflation. The margin of cost between hydro and thermal generation is thus narrowing steadily. A large coalburning base load plant on the waterfront of Toronto can deliver electric power at a cost only about fifty per cent higher than can the new hydro-installations at Niagara and on the St. Lawrence Seaway. (About 1920 thermal electric power cost three to five times as much as hydro-electric power in southern Ontario.) Provinces using thermal generation in the future will be Alberta, Saskatchewan (with cheap fossil fuels and natural gas), Ontario (with almost fully developed hydro-resources she is importing coal from the United States) and British Columbia (with cheap residual oil and natural gas). Gas turbine plants are being built in sizes from 2,000 to $25,000 \mathrm{~kW}$., but are unlikely to be used extensively because of their heavy fuel consumption compared with that of large steam turbines.

Canada has several large research reactors in operation, being particularly interested in heavywater moderated systems fuelled by natural uranium. (Heavy water has been produced in Canada and could be again. Uranium is found in abundance.) The large conventional resources still available in Canada make it likely that nuclear power will first be commercially developed elsewhere, with southern Ontario as an exception to that statement in view of its present need to import coal from the United States.

Dr. Grauer made some useful comments on longdistance transmission and the possibilities of a national power grid. Most transmission in Canada is at $230 \mathrm{kV}$., with $360 \mathrm{kV}$. being introduced in recent years. Distances of transmission have not exceeded about 250 miles, but much longer distances are in prospect. Ontario Hydro is planning 500 miles of $460-\mathrm{kV}$. line. The Peace River proposal envisages 600 miles at $500-600 \mathrm{kV}$., and tests are under way, both in Canada and the United States. Present thinking in the U.S.S.R. is that distances less than 600-800 miles are more efficiently met with alternating current, while for distances greater than this, direct current is more efficient. Canada's distances are similar to those in the U.S.S.R. However, potential developments are so placed relative to population centres that few distances of greater than 600 miles are contemplated. Three large potential hydrosituations in the far north are about a thousand miles from the chief market and their development will presumably await the d.c. transmission of the future. Dr. Grauer believes that a national power grid, for a number of reasons (not the least being that natural gas in large pipe-lines can be transported for less than one-third the cost of transporting electrical energy over the highest voltage lines) is more likely to evolve over a period of time from regional systems stronger and more highly developed than exist to-day.

The final paper of the conference, presented by Mr. S. F. Steward, director of the British Electrical and Allied Manufacturers' Association, was entitled "British Electrical Manufacture in the National Economy". The British Electrical and Allied Manufacturers' Association, the trade association of the electrical industry in Britain, is this year celebrating the fiftieth anniversary of its foundation. The main aim in establishing the new trade association in 1911 was "to foster some order and regulation in the trading of its constituent firms". It is interesting to note that within a year or two of the Association's foundation the annual report invited "the earnest attention of members to industrial and scientific research as one of the bedrocks of commercial supremacy".

Early attention was given to the legal conditions applicable to contracts for heavy plant, and, in association with the Institution of Electrical Engineers. model general conditions were drawn up which. when published in 1914, became the first standard text of its kind in the world. Technical and commercial co-operation, publicity and export promotion were early recognized as main functions of a trade association. Standards were issued as early as 1913 for the use of member firms, priority being given to the standardization of electrical machinery.

Mr. Steward reviewed in considerable detail the development of the electrical industry throughout five decades, emphasizing the extent to which electrical manufacture has become a key industry. About ten per cent of the total United Kingdom export of manufactured goods represents electrical equipment. The total number of employees in the industry is nearly $800,000,28$ per cent of this number being engaged in the manufacture of electrical machinery and 38 per cent on electronics and telecommunications equipment. Electrical manufacture is the largest industrial employer of scientists and technicians. In 1959 the industry employed 13,380 qualified scientists and engineers.

The drawing up of conditions of contract and contributions towards the establishment and maintenance of standards continue to be important activities of the Association. Of increasing importance is the collection and dissemination of statistics and information, the study of trends and of overseas competition. "A trade association must be a realistic partnership of competing concerns, not with the purpose of restricting competition but to secure the best use of an industry's resources and to provide the basis for the full development of initiative and enterprise".

\section{OBITUARIES}

\section{Prof. M. L. Anderson}

The death of Prof. M. L. Anderson, of the chair of forestry in the University of Edinburgh, occurred on September 6 at Bristol, while he and Mrs. Anderson were on a visit to their married daughter.

Mark Louden Anderson was born on April 16 , 1895, at Kinneff in Kincardineshire. $\mathrm{He}$ had the misfortune to lose both parents when he was only eleven years old. He entered the forestry course at the University of Edinburgh in 1912, but saw service throughout the First World War, first in the Argyll and Sutherland Highlanders and the Black Watch, and then in the Machine Gun Corps, winning the Military Cross in 1918. Returning to Edinburgh, he graduated B.Sc. (Forestry) in 1919, and five years 